\title{
A qualitative ecological risk assessment of the invasive Nile tilapia, Oreochromis niloticus in a sub-tropical African river system (Limpopo River, South Africa)
}

\author{
TSUNGAI A. ZENGEYA ${ }^{\mathrm{a}, \mathrm{c}}$, MARK P. ROBERTSON ${ }^{\mathrm{a}}$, ANTHONY J. BOOTH ${ }^{\mathrm{b}}$, \\ CHRISTIAN T. CHIMIMBA ${ }^{\mathrm{a}}$
}

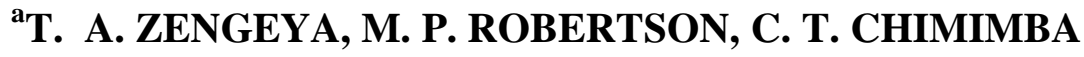 \\ DST-NRF Centre of Excellence for Invasion Biology (CIB) \\ Department of Zoology and Entomology \\ University of Pretoria, Private Bag X20 \\ Hatfield, 0028 South Africa
}

Tel: +27124204315

Fax: +27 123625242

Email: tzengeya@zoology.up.ac.za

\author{
${ }^{\mathrm{b}}$ A. J. BOOTH \\ Department of Ichthyology and Fisheries Science \\ Rhodes University, PO Box 94 \\ Grahamstown, 6140 South Africa
}

\section{${ }^{c}$ T. A. ZENGEYA}

Present address: Natural Resources and the Environment

Council for Scientific and Industrial Research (CSIR)

PO Box 395, Pretoria, 0001 South Africa 


\section{ABSTRACT}

1. This study outlines the development of a qualitative risk assessment method and its application as a screening tool for determining the risk of establishment and spread of the invasive Nile tilapia, Oreochromis niloticus (Linnaeus, 1758), within the central sub-catchment of the Limpopo River basin in northern South Africa.

2. The assessment utilised known physiological tolerance limits of $O$. niloticus in relation to minimum water temperature, presence or absence of dams, seasonality of river flows and the presence of indigenous fish species of concern to identify river systems that would be suitable for O. niloticus establishment.

3. River sections along the Limpopo main river channel and the immediate reaches of its associated tributaries east of the Limpopo/Lephalala river confluence along the Botswana-South AfricaZimbabwe border were identified as being highly vulnerable to O. niloticus invasion. Rivers in the upper Bushveld catchment (Upper Limpopo, Mogalakwena, Lephalala, Mokolo, Matlabas and Crocodile rivers) were categorised as of medium ecological risk, while headwater streams were considered to be of low ecological risk. The decrease in vulnerability between lowveld and highveld river sections was mainly a function of low water temperatures $\left(8-12^{\circ} \mathrm{C}\right)$ associated with increasing altitude.

4. Oreochromis niloticus is already established in the lower catchment of the Limpopo River basin where indigenous congenerics are at an extinction risk through hybridization and competition exclusion. Oreochromis niloticus, therefore, poses an ecologically unacceptable risk to novel river systems in the upper catchment where it is yet to establish. The current risk assessment model provides a useful preliminary logistic framework for the identification of river systems that are vulnerable to an $O$. niloticus invasion where conservation measures should be directed and implemented to prevent its introduction and spread within the Limpopo river system. 


\section{INTRODUCTION}

The adverse ecological impacts associated with fish introductions on recipient freshwater ecosystems worldwide have drawn attention to the need to control and manage the movement of invasive species (Sala et al., 2000; Cambray, 2003; Njiru et al., 2005; Pimentel et al., 2005). This has become especially important with the advent of increased global trade, transport and tourism that have afforded an opportunity for organisms to spread beyond their natural ranges (Copp et al., 2005; Gozlan et al., 2010). In response to this threat, most countries have implemented legislation prohibiting new introductions and some have developed adaptive management strategies to identify and minimise the impact of invasive species (Kolar, 2004; Vander Zanden and Olden, 2008). Prevention is the major tenet behind most invasive species management protocols as it is often much easier and significantly less costly especially for invasive aquatic species that are practically impossible to eradicate once established (Simberloff, 2003; Lockwood et al., 2007).

Ecological risk assessments have been widely used as a screening tool to identify potential invasive species and to assess the risk of adverse ecological impacts associated with a given species establishment and spread to ecosystem structure and functioning (National Research Council, 2002). An ecological risk assessment for invasive species consists of two main components: risk identification and risk management (Anderson et al., 2004; Webb, 2006). Risk identification is a process that evaluates the likelihood that adverse ecological effects may either occur or are occurring to indigenous congenerics as a result of exposure to introduced species. Risk of invasion is identified by either deductive and/or correlative methods. Deductive approaches utilise life history traits and environmental tolerances of an organism to evaluate the

likelihood that a species will transit all the invasion stages (initial dispersal, establishment, 
spread and impact) (Lockwood et al., 2007). For example, Schleier et al. (2008) developed a risk assessment based on habitat suitability (minimum water temperature, indigenous fish species of concern and the presence or absence of dams) to identify river systems in Montana (USA) watersheds that would be suitable for the establishment of the introduced mosquito fish Gambusia affinis. The major advantages of using such an approach to screen invasive species is that it is applicable to a variety of ecosystems and is easy to implement, modify and improve on as new data become available. It also highlights areas for future research by identifying areas of uncertainty within the model. The disadvantages associated with these deductive methods are that model development is data-intensive, there is limited transferability of model predictions (i.e., predictions limited to study area), and there are limited data available on failed introductions (Kolar and Lodge, 2002; Kolar, 2004).

Ecological niche modeling is a correlative method that utilizes associations between environmental variables and known species' occurrence localities to predict potential areas where a given species is likely to establish (e.g., Guisan and Thuiller, 2005; Elith et al., 2006; Elith and Leathwick, 2009). It has been successfully applied to a varied array of ecological disciplines that include ecology and evolutionary biology, impacts of climatic change, invasion biology and conservation biology (see Guisan and Thuiller, 2005 for a review on the development and applications of ecological niche models). Ecological niche models have been successfully applied to predict the potential distribution of invasive fish species in novel systems (e.g., Igushi et al., 2004; McNyset, 2005; Zambrano et al., 2006; Chen et al., 2007) but like deductive methods, they also have limitations to their application (Elith et al., 2006; Fitzpatrick et al., 2007). In particular, several studies have shown that niche models developed using native range occurrences may fail to predict the full extent of an invasion. This failure has often been 
attributed to changes in the niche of the invading species (Fitzpatrick and Hargrove, 2008), biotic interactions and dispersal limitations that prevent the species from occupying potential suitable habitats (Anderson et al., 2002) and the choice of environmental variables used to train the models (Peterson and Nakazawa, 2008; Rödder et al., 2009; Rödder and Lötters, 2009, 2010). Despite these caveats, deductive and correlative approaches are widely applied as a screening tool to identify potential invasive species and prevent their transmission into novel river systems (e.g., Pheloung et al., 1999; Kolar and Lodge, 2002; National Research Council, 2002; Kolar, 2004; Marchetti et al., 2004; Copp et al., 2005; Schleier et al., 2008).

Risk management involves the use of decision-support systems to estimate the risk of adverse ecological impacts associated with a given species establishment and spread to ecosystem structure and functioning in relation to environmental, social, and economic values of a given region (Copp et al., 2005). Risk management also enables concerned stake-holders to prioritise resource allocation for effective preventative and remediation efforts (Anderson et al., 2004; Copp et al., 2005).

This study investigates the ecological risk associated with the invasive Nile tilapia Oreochromis niloticus (Linnaeus, 1758) in the central sub-catchment of the Limpopo River basin, northern South Africa. Native to the Nile River basin, Lake Chad, south-western Middle East and the Niger, Benue, Volta and Senegal Rivers (Daget et al., 1991), O. niloticus has been widely introduced in southern Africa for aquaculture and feral populations are now established in most river catchments within the sub-region (van Schoor, 1966; de Moor and Bruton, 1988; Welcomme, 1988; Schwank, 1995; Chifamba, 1998; Skelton, 2001; Marshall, 2006; Weyl, 2008; Zengeya and Marshall, 2007). These feral populations have been implicated in causing adverse effects on the recipient river systems such as decreased indigenous fish abundance and local 
extinction of indigenous congenerics through competitive exclusion and hybridisation (Chifamba, 1998; Moralee et al., 2000; van der Waal and Bills, 2000; D’ Amato et al., 2007).

In South Africa, O. niloticus was initially introduced in the Cape Flats area (Cape Town, Western Cape Province) and in KwaZulu-Natal Province in the 1950s for aquaculture (van Schoor, 1966). Its distributional range has since expanded to include the Limpopo River and other eastern rivers in South Africa and Mozambique where it is now established and spreading (van der Waal and Bills 1997, 2000; Weyl, 2008). The advent of O. niloticus in the Limpopo river system is a cause for concern for the conservation of indigenous congenerics, especially for Mozambique tilapia $O$. mossambicus that is likely to become extirpated from the river system through hybridization and competition arising from its habitat and trophic overlaps with that of O. niloticus (Cambray and Swartz, 2007). Other indigenous tilapiines in the Limpopo River system include black tilapia $O$. placidus, redbreast tilapia Tilapia rendalli and banded tilapia $T$. sparrmanii. Greenhead tilapia $O$. macrochir is only known from one occurrence record (Kleynhans \& Hoffman, 1992) and might have failed to establish itself.

The ecology of seasonal rivers within the Limpopo river system is poorly understood and as a result of the lack of earlier information on the hydrology as well as biota, recent changes and environmental deterioration have not been recorded (van der Waal, 1997; van der Mheen, 1997; Davies and Wishart, 2000). The impact of $O$. niloticus on indigenous fish communities in the Limpopo River system may be especially severe in rivers systems impacted by anthropogenic activities such a dam construction, pollution, siltation, invasive alien weeds and habitat destruction (Skelton, 1990). It is therefore critical to identify areas within the Limpopo river basin where $O$. niloticus has been introduced, predict which river system(s) are vulnerable and 
possibly at risk of further Nile tilapia invasions, and more importantly, what can be done to stop its spread and reduce its impact.

In response to these knowledge gaps, this study developed a qualitative risk assessment method based on Schleier et al. (2008) and outlines its potential use as a screening tool for determining the risk of establishment and spread of $O$. niloticus within the central sub-catchment of the Limpopo river basin, northern South Africa. Ideally, ecological risk assessments should be quantitative but in cases where there are insufficient data on community structure and functioning, qualitative approaches have been successfully applied (Anderson et al., 2004; Colnar and Landis, 2007; Schleier et al., 2008). This study considered the use of ecological risk assessment to predict the risk of establishment for $O$. niloticus in the central sub-catchment of the Limpopo River basin, northern South Africa and the major implications for the conservation of indigenous congenerics. 


\section{METHODS}

\section{Problem formulation}

Ecological risk assessment is defined herein as a process that evaluates the likelihood that adverse ecological effects may either occur or are occurring to indigenous congenerics in the Limpopo river basin, South Africa as a result of exposure to O. niloticus. The assessment was divided into four principal components according to Landis (2004) and Schleier et al. (2008). The assessment determined both the risk of $O$. niloticus establishment and spread, and the potential detrimental effects it may have on indigenous congenerics and other species of concern (hereafter referred to as SOC) within the Limpopo river basin.

The first component described the organism of interest, or stressor, as O. niloticus and outlined its known or potential adverse ecological impacts on receiving environments. The second component identified assessment end-points as indigenous congenerics, other indigenous species of concern (SOC), and rivers and streams that are at risk of an $O$. niloticus invasion within the Limpopo River basin. The third component consisted of an exposure analysis to estimate the likelihood of introduction, establishment and spread of O. niloticus within river systems in the Limpopo River basin by identifying the physiological tolerance of $O$. niloticus in relation to minimum water temperature in the receiving environment that would be suitable for the species establishment. The last component integrated the information from the second (assessment analysis) and third (exposure analysis) steps to generate a risk characterisation for $O$. niloticus establishment and potential impact to indigenous congenerics and species of concern. 


\section{Stressor description}

Nile tilapia has been introduced worldwide for aquaculture, augmentation of capture fisheries, and sport fishing (Trewavas, 1983; Welcomme, 1988). It is well-suited for aquaculture because of its wide range of trophic and ecological adaptations, and its adaptive life history characteristics enable it to occupy many different tropical and sub-tropical freshwater niches (Trewavas, 1983). These include a high reproductive rate and a remarkable physiological hardiness, adaptability and general level of tolerance to most potentially limiting environmental variables (Chervinski, 1982; Philippart \& Ruwet, 1982). Nile tilapia is eurythermal and tolerates a wide range of temperatures $\left(8-42^{\circ} \mathrm{C}\right)$ with a preferred optimal range between 31 and $36^{\circ} \mathrm{C}$ (Philippart \& Ruwet, 1982; Sifa et al., 2002; Atwood et al., 2003; Charo-Karisa et al., 2005). Its salinity upper tolerance ranges from $20-30 \mathrm{~g} . \mathrm{l}^{-1}$ according to body size, age, and environmental factors such as water temperature (Watanabe et al., 1985; Villegas, 1990; Likongwe et al., 1996; Lemarie et al., 2004). Optimal growth is achieved when salinity is $<5 \mathrm{~g} . \mathrm{l}^{-1}$ (Payne and Collinson, 1983). Oreochromis niloticus is also a highly adept invader that is able to utilise degraded habitats in contrast to observed decreased abundance of indigenous congenerics in similar imperilled systems (Zengeya and Marshall, 2007; Linde et al., 2008)

Oreochromis niloticus is a microphage that is known to feed selectively on phytoplankton (Moriarty and Moriarty, 1973; Getabu, 1994; Bwanika et al., 2004; Zengeya and Marshall, 2007; Zengeya et al., 2011). Trophic distinctions for $O$. niloticus are, however, not always clearly defined and the species is known to exhibit opportunistic and versatile feeding strategies that reflect the abundance and composition of food sources in different environments, seasons and either the presence or absence of competing fish species and predators (Gophen et al., 1993; 
Balirwa, 1998; Njiru et al., 2004; Njiru et al., 2007; Zengeya \& Marshall 2007, Zengeya et al., 2011).

The reproductive biology of $O$. niloticus is characterised by fast growth rate, early sexual maturity (5 - 6 months), a high degree of parental care, ability to spawn multiple broods in a season and high fecundity associated with its large body size (Trewavas, 1983; Ojuok et al., 2007). It is known to attain approximately $60 \mathrm{~cm}$ (standard length) and large males are often aggressive competitors that out-compete other species for spawning and mouth-brooding grounds, if these are limited (Lowe-McConnell, 2000). These attributes have inherently predisposed it to be a successful invasive species, with established feral populations in most tropical and sub-tropical environments in which it has either been cultured or has otherwise gained access (Welcomme, 1988; Pullin et al., 1997; Costa-Pierce, 2003; Canonico et al., 2005).

\section{Assessment of impacts}

Invasion risk of $O$. niloticus to its indigenous congenerics is defined as the product of the likelihood of $O$. niloticus becoming successfully established in a given novel river system and the associated adverse ecological consequences (National Research Council, 2002). The highest risk scenarios are likely to unfold when there is both a high probability of the establishment of $O$. niloticus in recipient river systems and associated adverse ecological impacts. In most tropical rivers the actual impact of introduced species is difficult to ascertain because data on the community structure and functioning before the introductions are often unavailable. Despite this, the well-documented success of $O$. niloticus in invading novel tropical river systems worldwide and associated adverse effects (see Canonico, 2005 and references therein), provide strong 
circumstantial evidence to support the hypothesis of increased extinction rates and hybridisation risk to indigenous congenerics in recipient river systems as a result of $O$. niloticus invasions.

The mechanism of potential adverse ecological impact of $O$. niloticus include competition for food and the space necessary for spawning and mouth brooding. In areas where it has become established, $O$. niloticus has been shown to rapidly displace indigenous congenerics through competitive exclusion, to the extent that some populations have become locally extinct. For example, in Lake Kariba, Nile tilapia appeared in the mid-1990s after escaping from in situ cage-culture fish farms and has become abundant at the expense of Kariba tilapia O. mortimeri that has declined significantly in abundance (Chifamba, 1998; Marshall, 2006). As a result, Kariba tilapia is now listed as Critically Endangered (CR) on the IUCN Red List of threatened species (Marshall and Tweddle, 2007). This has also been noted in Lake Victoria, where the introduced Nile tilapia has displaced the native $O$. variabilis and $O$. esculentus (de Vos et al., 1990; Goudswaard et al., 2002; Balirwa et al., 2003). The success of Nile tilapia has been attributed to its opportunistic feeding behaviour (Getabu, 1994; Njiru et al., 2004), utilisation of a typically unoccupied phytoplanktonic trophic niche (Zengeya et al., 2011), parental care, high juvenile survival, fast growth rate (Balirwa, 1998), and its ability to utilize a wide range of habitats for spawning and nursery purposes (Twongo, 1995).

Few studies have assessed the potential of $O$. niloticus to transmit diseases into novel aquatic systems and the only recent investigation was from Lake Nicaragua (Central America) (McCrary et al., 2007), where an out-break of trematodes that affected several cichlid species was linked to the dominance of both $O$. mossambicus and $O$. niloticus in the lake system. This notwithstanding, several bacteria and parasitic diseases are known to affect tilapias (Shoemaker et al., 2006) and studies of disease transmission by other invasive fish species elsewhere have 
demonstrated the potential of invasive fish species to spread pathogens into recipient aquatic systems (Gozlan et al., 2005). Another potential impact of O. niloticus is habitat alteration through increased nutrient loading from bio-turbation and nutrient recycling of ingested and excreted material, which can lead to accelerated eutrophication, with associated algal blooms and excessive growth of aquatic macrophytes (Starling et al., 2002; Figueredo and Giani, 2005). Oreochromis niloticus can also alter aquatic habitats by the removal of underwater vegetation as reported in Nicaragua, where the decline of Chara sp. beds was associated with the spread and establishment of O. niloticus (McCrary et al., 2007) and a decline in indigenous species as a result of habitat loss and modification. It has also been implicated in hybridisation with other tilapiines such as O. mossambicus in the Limpopo River Basin (Moralee et al, 2000; van der Waal \& Bills, 2000; D’Amato et al., 2007). As with other cichlids, the tilapiines underwent a recent evolutionary radiation, and either recent or incomplete speciation processes allow them to hybridise readily, posing a threat to the integrity of local adaptation (D'Amato et al., 2007).

Despite the well-documented adverse ecological effects of $O$. niloticus on recipient river systems (see Canonico, 2005 and references therein), it is among one of the most widely cultured species in aquaculture and stock enhancements (Suresh, 2003). While aquaculture is perceived as a means of achieving protein security, poverty alleviation and economic development in many developing countries (NEPAD, 2005), the decisions on exotic fish introductions are usually based on the trade-off between socio-economic benefits and potential adverse ecological effects (Cowx, 1999). In most invaded aquatic systems, O. niloticus has had a pronounced impact on fisheries in terms of increased food production and poverty alleviation by creating alternative aquaculture and fisheries livelihoods (Wise et al., 2007). Interestingly, the establishment of $O$. niloticus in novel aquatic systems has not led to a decrease in overall yields, but rather the 
replacement of indigenous species (Ogutu-Ohwayo, 1991; Twongo, 1995; Balirwa et al., 2003; Shipton et al., 2008; Weyl, 2008). In a few cases, O. niloticus has supplanted desirable species from fisheries such as in Lake Victoria, where it is often regarded as being of inferior quality in comparison to the various haplochromines that it supplanted and, therefore, commands lower market prices (Wise et al., 2007).

\section{Assessment end-points}

\section{Species of concern}

Species of concern (SOC) are defined herein as species within the Limpopo River basin (Table 1) that are either declining or appear to be in need of concerted conservation actions as a result of a combination of their restricted natural range and escalating anthropogenic activities such as pollution, habitat alteration, water abstraction, dam construction, inter-basin water transfer schemes and introduced species (Skelton, 1990; Davies et al., 1992; Tweddle et al., 2009). The advent of $O$. niloticus in the Limpopo river system is a cause for concern for the conservation of indigenous congeneric species, especially O. mossambicus (Cambray and Swartz, 2007). The other indigenous tilapiines in the Limpopo river system such as Tilapia rendalli and $T$. sparrmanii have low habitat and trophic overlaps with $O$. niloticus and will likely not be significantly affected by the establishment of $O$. niloticus. This study also included the southern barred minnow Opsaridium peringueyi that occurs naturally from the Save river system in Zimbabwe down to the Pongola river system in South Africa as a species of concern. It is listed as vulnerable because of its reduced distributional range through habitat alteration of flowing rivers by impoundments and excessive water abstraction (Skelton, 2001). It is reported as 
possibly extinct in Zimbabwe as a result of severe drought and habitat alteration (Marshall and Gratwicke, 1999).

\section{Other introduced species}

The assessment of end-points in this study also included other introduced species (hereafter referred to as OIS). These include mosquito fish Gambusia affinis, bluegill sunfish Lepomis macrochirus, rainbow trout Oncorhynchus mykiss and largemouth bass Micropterus salmoides. The OIS were included as they are known to cause severe biological impacts on small riverine species and juveniles of large species elsewhere (Cambray 2003; Woodford and Impson, 2004; Gratwicke and Marshall, 2001).

\section{Assessment of exposure}

An assessment of exposure in this study was done to estimate the likelihood of introduction, establishment and spread of $O$. niloticus within river systems in the Limpopo River basin. The physiological tolerance limits of $O$. niloticus in relation to minimum water temperature were used to identify river systems that would be suitable for the species' establishment. Data layers summarising the main river systems and dams within the Limpopo River system were obtained from Resource Quality Services, Department of Water Affairs, South Africa (http://www.dwaf.gov.za/iwqs) and were analysed using ArcMap ${ }^{\circledR}$ 9.3. (ArcGIS ${ }^{\mathrm{TM}}$; ESRI ${ }^{\circledR}$, Redlands, CA). Additional data summarising estimated annual predictions of mean monthly water temperature variables (maximum, median, minimum and range) were obtained from the

African Water Resources Database (AWRD; Jenness et al., 2007; http://www.fao.org/geonetwork). A river segment was defined by first plotting a geographical 
grid of the main river systems within the Limpopo drainage basin. The grid was then superimposed onto a raster file of estimated mean monthly minimum water temperature (native pixel size of 30 arc seconds) from which the respective temperature values for each grid cell along a given river channel were extracted.

Nile tilapia can tolerate a wide range of temperatures $\left(8-42{ }^{\circ} \mathrm{C}\right)$ with a preferred optimal temperature range from 31 to $36{ }^{\circ} \mathrm{C}$ (Philippart \& Ruwet, 1982). However, the natural fitness of O. niloticus in terms of respiration, feeding, growth and reproduction is reduced at sub-optimal temperatures below $20{ }^{\circ} \mathrm{C}$ (Ross 2000). Oreochromis niloticus exhibits severe cold stress symptoms such as cessation of feeding, rapid and disoriented movement at temperatures below 15 C (Amoudi et al., 1996; Atwood et al., 2003; Charo-Karisa et al., 2005). Its lower lethal temperature limit varies between 8-12 ${ }^{\circ} \mathrm{C}$ (Likongwe et al., 1996, Sifa et al., 2002; Atwood et al., 2003; Charo-Karisa et al., 2005). River channels were therefore classified into three categories: $8-12{ }^{\circ} \mathrm{C}$ was characterised as of low risk (score $=1$ ), $12-15^{\circ} \mathrm{C}$ as of medium risk (score $=2)$, and $>15^{\circ} \mathrm{C}$ as of high risk $($ score $=3)$.

Within southern Africa, O. niloticus has been extensively propagated by farmers and anglers for recreational and sport fishing into small and medium reservoirs around the subregion. A positive spatial linkage between fish introductions for recreational and sport fishing and the presence of reservoirs within river catchments is well-documented elsewhere (Pringle $e t$ al., 2000; Marchetti et al., 2004; Han et al., 2008). For the purposes of this study, it was hypothesised that the successful establishment and spread of $O$. niloticus within the river system will likely have a strong spatial linkage with the presence of impoundments. Hence, the presence of a dam within a given river section was assigned a score of 2 and absence of impoundments was scored as 1 . 
The highly seasonal nature of river systems within the Limpopo river basin determines the availability of habitats for aquatic fauna (van der Waal, 1997; Minshull, 2008), hence, river channels were categorised either as perennial rivers and/or episodic/ephemeral rivers. Perennial rivers are defined as rivers with relatively regular, seasonally intermittent discharge (Davies et al., 1995) and were assigned a risk score of 2. Episodic/ephemeral rivers are defined as rivers that flow for short periods after high rainfall in their catchments (Uys and O'Keeffe, 1997) and were assigned a risk score of 1.

The exposure of indigenous congenerics and SOC was herein defined as the presence of O. niloticus within a given river section of the river basin where the respective indigenous species naturally occur. Firstly, if $O$. niloticus was present within a given section of the river, the river section was assigned a score of 3 (high risk), and if $O$. niloticus was absent within a given section of the river but present in upper reaches of the river it was assigned a score of 2 (medium risk). If $O$. niloticus was absent from both upper and immediate reaches of a given river section, it was assigned a score of 1 (low risk). Secondly, if an SOC occurs within a given river section, the river segment was assigned a score of 2 and if no SOC are known to occur within a given river section it was assigned a score of 1. Lastly, if an OIS was known to be present within a given river segment, it was assigned a score of 2 , and if a river section had no known record of introductions, it was given a score of 1 .

Geo-referenced occurrence data for summarising species distributions were obtained from various sources including museum specimen records, biodiversity databases such as FishBase (http://www.fishbase.org), Global Biodiversity Information Facility (GBIF; http://www.gbif.org), the published literature, and fish survey data from various fisheries departments in southern African countries that included Botswana, Mozambique, Zambia, and 
Zimbabwe. A fish survey was also conducted from December 2008 - December 2009 on the Limpopo River and its associated tributaries within the Limpopo Province of South Africa to ascertain the extent of the current distribution of $O$. niloticus within the province from previously known introduction sites. The presence or absence of $O$. niloticus within a given river segment was confirmed through genetic and morphological identification of sampled populations in a parallel on-going study.

\section{Characterisation of risk}

\section{Invasion vulnerability}

The invasion vulnerability score (IVS) was derived as the sum of all physical variables (minimum temperature), dam score and river flow (either perennial or episodic/ephemeral) for each given river section. The minimum possible IVS was 3 and the maximum possible was 7. The IVS values were then divided into three risk categories using the natural break (Jenks), in Arc-Map® 9.3 where rivers with river segments with IVS values $<4$ were characterised as of low risk, 4 - 5 as of medium risk, and 6 - 7 as of high risk.

\section{Invasion impact}

The invasion impact score (IIS) was calculated as the sum of $O$. niloticus exposure, SOC and OIS scores for each given river section. The minimum possible IIS was 5 and the maximum possible was 10. The IIS values were divided into two risk categories using the natural break (Jenks), in Arc-Map ® 9.3 where rivers segments with IIS values between 5 - 8 being characterised as of low risk and those between 9 - 10 as of high risk. 


\section{RESULTS}

\section{Invasion vulnerability}

The river sections centred on the Limpopo main river channel and the immediate reaches of its associated tributaries east of the Limpopo/Lephalala river confluence along the Botswana-South Africa-Zimbabwe border recorded the highest possible IVS (6 - 7) for O. niloticus establishment (Fig. 1). This was mainly attributed to a suitable receiving environment in terms of minimum temperature $\left(15-19^{\circ} \mathrm{C}\right)$, perennial availability of water and the presence of large numbers of reservoirs. In the upper Bushveld catchment, the Upper Limpopo, Mokolo, Matlabas and Crocodile rivers had IVS values between 4 and 5, which was categorised as medium risk. Headwater streams, especially in the Waterberg escarpment, recorded the lowest IVS of 3 relative to all other river sections. The decrease of the IVS values was mainly a function of low water temperature $\left(8-12{ }^{\circ} \mathrm{C}\right)$ associated with increasing altitude and availability of water.

\section{Invasion impact}

A total of 92 of 290 (32\%) river sections are at high risk of adverse impacts on indigenous riverine species from an $O$. niloticus invasion (Fig. 2). The Limpopo River's main river channel and its associated tributaries such as the Crocodile, Matlabas, Mokolo, and Luvhuvhu rivers recorded the highest possible IIS values $(9$ - 10) for $O$. niloticus establishment. The Limpopo River recorded high IIS scores mainly as a result of the presence of established $O$. niloticus feral populations east of the Shashe/Limpopo rivers confluence along the Botswana-South AfricaZimbabwe border, while the remainder (Crocodile, Matlabas, Mokolo, and Luvhuvhu rivers), the high ORS scores can be attributed to the presence of other introduced species such as $M$. salmoides and C. carpio in the respective segments. 


\section{Uncertainty analysis}

A major limitation for the application of ecological risk assessment to African freshwater systems is the general lack of ground-truthed aquatic environmental data (water quality variables, habitat availability and quality), and the scarcity of up-to-date, accurate and easily accessible species occurrence records. To circumvent the lack of aquatic environmental data, proxy estimates of annual water temperature trends derived from air temperature bio-climatic variables (Jenness et al., 2007) were used instead as they have been successfully applied to delimit areas where temperature might be a limiting factor to aquaculture production of $O$. niloticus and sharp tooth catfish, Clarias gariepinus within Africa (Kapetsky, 1994).

To ascertain the accuracy of the water temperature estimates, limited available data from 1950 to 2009 summarising annual temperature (mean, minimum and maximum) trends within the Limpopo river system was obtained from the Directorate of Resource Quality Services, Department of Water Affairs, South Africa (http://www.dwaf.gov.za/). Data summarising annual temperature trends between 1950 and 2009 were collated from 25 monitoring stations. Estimated temperature values were then extracted using Arc-Map® 9.3 for the selected monitoring stations and found to be significantly related to actual temperatures $(P<0.05)$. The regression $\left(r^{2}\right)$ models only explained at most $33 \%$ of the variability of the observed temperature data. This indicates that estimated air temperatures are poor predictors of actual water temperatures. This disparity between actual and predicted air temperature could be partly due to the quality/accuracy of the available data. The available temperature data were patchy in spatial and temporal terms and were only available for certain years and for a small number of monitoring stations. These water temperature estimates are currently the best available data on 
thermal regimes within African river systems and must therefore be viewed as proxies when actual water temperature data are unavailable.

It was hypothesised that $O$. niloticus will not be able to establish in rivers that have a minimum temperature lower than $10^{\circ} \mathrm{C}$ (Likongwe et al., 1996; Sifa et al., 2002; Atwood et al., 2003; Charo-Karisa et al., 2005). It is however uncertain on how long and how frequently fish are exposed to this lethal limit. It was therefore prudent to analyse the mean and range of monthly water temperature to identify river systems that had favourable thermal regimes for the establishment of $O$. niloticus. In general, a decrease in mean water temperature and an increase in the amplitude of temperature fluctuations with increasing altitude were observed. River systems in the low-lying central river valley have mean monthly water temperatures of $>20{ }^{\circ} \mathrm{C}$ and a low range $\left(<12{ }^{\circ} \mathrm{C}\right)$ of temperature fluctuations. The mean monthly temperature is $20^{\circ} \mathrm{C}$ in the middle reaches and $16^{\circ} \mathrm{C}$ in the upper reaches. It is possible that $O$. niloticus might be able to over-winter in those environments where the amplitude of the annual thermal range is reduced by the presence of infrastructures such as dams and weirs. 


\section{DISCUSSION}

The overall level of risk for the establishment of O. niloticus within the Limpopo basin was projected as high for the central river valley and moderate for river systems in the upper Bushveld catchment. The difference in overall risk score between the two areas was expected and is a composite of the three stages of invasion, namely, initial dispersal, establishment, and spread.

\section{Initial dispersal}

There are already established feral populations of $O$. niloticus along the channel of the Limpopo River and in the immediate reaches of its associated tributaries east of the Shashe/Limpopo rivers confluence, while it has yet to establish within river systems in the upper bushveld subcatchment (van der Waal, 2007; Zengeya et al., 2011). The presumed source of introduction of O. niloticus into the Limpopo system is from the Zimbabwean sub-catchment of the Limpopo river where $O$. niloticus has been extensively propagated by farmers and anglers for aquaculture, recreational and sport fishing (van der Waal and Bills 1997, 2000; Marshall, 2000). It has inevitably spread down-stream into the Limpopo river system and its continued propagation in the upper catchments is likely to ensure a sustained influx of propagules into down-stream river systems.

The spread of $O$. niloticus into rivers and streams in the upper catchment may have been retarded by a limited natural dispersal pathway. As a result of the semi-arid climate and the unpredictable rainfall within the Limpopo River basin, water availability for human use has been secured through the construction of small- to medium-sized impoundments. This has led to a high degree of river fragmentation with 25 dams (>15 m high) constructed within the river 
system. The physical barriers imposed by such dam and weir systems and the highly seasonal and episodic/ephemeral surface water flows are likely to restrict the natural up-stream migration of O. niloticus into the bushveld upper sub-catchment (van der Waal, 2007). Although not integrated into the analysis of the model used in the present study, the idiosyncratic behaviour of humans as agents of spread of invasive fish species is likely to be an important driver of the spread of $O$. niloticus further up-stream of the Limpopo river catchment. In southern Africa, $O$. niloticus invasion seems to be highly correlated with human activities such as aquaculture and angling and the presence of impoundments. However, detailed studies on fish population dynamics within respective impoundments, their spatial linkages and correlation with land use patterns are needed to evaluate this hypothesis.

\section{Establishment}

The presence of large dams within the river system is also likely to promote $O$. niloticus invasion by increasing colonization opportunities through the provision of suitable habitats. Dams and impoundments greatly change the distribution of surface water and modify habitats (Havel et al., 2005). This is especially noticeable in water-scarce environments such as the Limpopo River basin where rivers recede into long stretches of dry sand, interspersed by a staggered series of residual pools, weirs and farm dams during the dry season (van der Waal, 1997; Minshull, 2008). These seasonal pools and small impoundments provide dry season refuges for fish and have been shown to support diverse fish communities in relatively high densities comparable to more stable and productive ecosystems elsewhere (Minshull, 2008).

Impoundments are also likely to modulate the observed large monthly water temperature range from the extremes. In comparison to river systems, the relatively greater depth of water in 
a reservoir has a modulating effect on temperature extremes (Wetzel, 2001). The thermal regimes of rivers in the upper Bushveld reveal that headwater streams, especially in the Waterberg escarpment, experience minimum water temperature below $10{ }^{\circ} \mathrm{C}$ and have higher amplitude of temperature fluctuations between the minimum and maximum monthly temperatures relative to the middle and lower reaches. It is, therefore, possible that $O$. niloticus might be able to over-winter in environments that are able to reduce the amplitude of the annual thermal range from extremes. Oreochromis niloticus is among the most cold-tolerant tilapia because the species can survive at elevations of between 1500 and $2000 \mathrm{~m}$ (Trewavas, 1983). The water temperature profile for rivers becomes progressively warmer with decreasing elevation and the mean monthly temperature for most rivers in the lower catchment is above 20 ${ }^{\circ} \mathrm{C}$. There is also a marked decrease in the amplitude of temperature fluctuations with decreasing altitude. Therefore, the Upper Limpopo, Mogalakwena, Lephalala, Mokolo, Matlabas and Crocodile rivers were categorised as of medium risk, where $O$. niloticus may be able to overwinter and establish provided other factors such as water availability are not limiting.

\section{Potential impact}

Oreochromis niloticus is a highly successful invader and this is attributed to its extreme hardiness, wide range of trophic and ecological adaptations, and its adaptive life history characteristics. We therefore consider that $O$. niloticus poses an unacceptable risk to its congenerics in the Limpopo River system. Of particular concern is that in systems within the Limpopo River basin where $O$. niloticus has already invaded and established feral populations, adverse ecological impacts such as reduced abundance of indigenous species and hybridisation 
with its congenerics have already been documented (D' Amato et al., 2007; Tweddle and Wise, 2007; Weyl, 2007).

Adverse ecological impacts of introduced fish in the Limpopo River system may be accentuated further by other anthropogenic ecosystem stressors such as pollution and habitat modification (Ashton, 2007). For example, in Lake Victoria, anthropogenic eutrophication and the introduction of the Nile Perch Lates niloticus and O. niloticus led to a decline and local extinction of indigenous haplochromines through habitat modification, predation pressure from L. niloticus and competitive exclusion from O. niloticus (Witte et al., 1992; Seehausen et al., 1997; Goudswaard et al., 2002, Balirwa et al., 2003). In the Limpopo River basin, other invasive fish species such as $M$. salmoides and $C$. carpio have been widely introduced into most medium- to small-sized dams in the upper catchments of the Crocodile, Mokolo and Luvhuvhu rivers (Kleynhans et al., 2007). The projected impact of O. niloticus on indigenous fish communities is likely be severe in the Limpopo River system that is already imperilled by extreme environmental conditions associated with a seasonal and semi-arid climate (Davies and Wishart, 2000) and effluent discharges from cities and towns in the upper catchments (Ashton, 2007). Return flows from planned inter-basin water transfers are also likely to change the hydrology and biotic integrity of recipient river systems as observed in adjacent river catchments (Davies et al., 1992)

\section{Are qualitative risk assessments useful?}

The qualitative risk model presented in this study provides a preliminary logistic framework for assessing the probability of $O$. niloticus establishment within the Limpopo River basin. This was done by identifying the physiological tolerance of $O$. niloticus in relation to minimum water 
temperature in the receiving environment that would be suitable for the species' establishment. The probability of a successful $O$. niloticus invasion is inherently tied to other factors such as propagule pressure and biotic interactions. However, in the absence of quantitative data on population processes and inter-specific interactions, an ecological risk assessment based on the habitat suitability at least remains an objective method that is easy to implement, modify and can be improved on in a logical and systematic manner as new data become available. It also serves as a guide for future research by identifying areas of uncertainty within the model where additional data are either required or further research is needed to improve model efficiency.

Globally, there is a lack of real-time monitoring of physical and chemical data for most rivers systems. The use of real-time data loggers to collect data on basic physico-chemical variables should be encouraged because they save on cost related to manual real-time data acquisition. Data loggers are able to obtain data automatically on a 24-hour basis, and will help improve the understanding of daily thermal regimes that might affect fish populations in specific river systems. There is also a need to implement regular monitoring programmes in most river catchments for introduced species and also to educate farmers and anglers about the ecological impacts that invasive species such as $O$. niloticus have on indigenous congenerics. As is often the case in management of invasive species, resources for detailed field studies and quantitative risk assessment procedures tend to be limited. The risk assessment model presented here based largely on proxies of environmental data can be used to identify river segments that are highly vulnerable to the establishment of the invasive Nile tilapia. Concerted conservation efforts can then be directed in such areas to confirm establishment, direct remediation efforts and contain further spread. For example, in South Africa, O. niloticus is listed as a potential invasive species under the National Environmental Management (NEMA): Biodiversity Act (Number 10, 2004), 
and it's stocking and utilisation is to be regulated through a zoning process. The delineation of high risk areas, as highlighted in this model can help stake-holders and managers to decide where in the river system indigenous congenerics are most vulnerable to $O$. niloticus invasion and where it is likely to spread.

\section{ACKNOWLEDGEMENTS}

This project was funded by the South African Working for Water (WfW) Project through the DST-NRF Centre of Excellence for Invasion Biology (CIB), University of Pretoria, South Africa. The Department of Water Affairs, South Africa is acknowledged for providing water temperature data. Peter Ashton (CSIR, South Africa) and Neels Kleynhans (Resource Quality Services, Department of Water Affairs, South Africa) are also acknowledged for commenting on drafts of this manuscript giving many valuable suggestions which greatly improved its quality.

\section{REFERENCES}

Al-Amoundi M, El-Sayed AFM, El-Ghobashy A. 1996. Effects of thermal and thermo-haline shocks on survival and osmotic concentration of the tilapias Oreochromis mossambicus and Oreochromis aureus $\times$ Oreochromis niloticus hybrids. Journal of World Aquaculture Society 27: 456-461.

Anderson MC, Adams H, Hope B, Powell M. 2004. Risk assessment for invasive species. Risk Analysis 24: 787-793.

Anderson RP, Peterson AT, Gómez-Laverde M. 2002. Using niche-based GIS modeling to test geographic predictions of competitive exclusion and competitive release in South American pocket mice. Oikos 98: 3-16. 
Ashton PJ. 2007. Riverine biodiversity conservation in South Africa: current situation and future prospects. Aquatic Conservation: Marine and Freshwater Ecosystems 17: 441-445.

Atwood HL, Tomaso JR, Webb K, Gatlin DM. 2003. Low-temperature tolerance of Nile tilapia, Oreochromis niloticus: effects of environmental and dietary factors. Aquaculture Research 34: $241-251$.

Balirwa JS, Chapman CA, Chapman LJ, Cowx IG, Geheb K, Kaufman L, Lowe-McConnell RH, Seehausen O, Wanink JH, Welcomme RL, et al. 2003. Biodiversity and Fishery Sustainability in the Lake Victoria Basin: An Unexpected Marriage? Bioscience 53: 703715.

Balirwa JS. 1998. Lake Victoria wetlands and the ecology of the Nile tilapia, Oreochromis niloticus Linne. $\mathrm{PhD}$. dissertation. Wageningen, The Netherlands: Wageningen Agricultural University.

Bwanika GN, Makanga B, Kizito Y, Chapman LJ, Balirwa J. 2004. Observations on the biology of Nile tilapia Oreochromis niloticus L. in two Ugandan crater lakes. African Journal of Ecology 42: 93-101.

Cambray J, Swartz E. 2007. Oreochromis mossambicus. In IUCN 2009, IUCN Red List of Threatened Species. Version 2009.2. Available at www.iucnredlist.org. Accessed 9 February 2010.

Cambray JA. 2003. Impact on indigenous species biodiversity caused by the globalisation of alien recreational freshwater fisheries. Hydrobiologia 500: 217-230.

Canonico GC, Arthington A, McCrary JK, Thieme ML. 2005. The effects of introduced tilapias on native biodiversity. Aquatic Conservation: Marine and Freshwater Ecosystems 15: 463483. 
Charo-Karisa H, Rezk MA, Bovenhuis H, Komen H. 2005. Heritability of cold tolerance in Nile tilapia, Oreochromis niloticus, juveniles. Aquaculture 249: 115-123.

Chen P, Wiley EO, McNyset KM. 2007. Ecological niche modelling as a predictive tool: silver and bighead carps in North America. Biological Invasions 9: 43-51.

Chervinski J. 1982. Environmental physiology of tilapias. In The Biology and Culture of Tilapias, Pullin RSV, Lowe-McConnell RH (eds). ICLARM Conference Proceedings 7: 119-128.

Chifamba PC. 1998. Status of Oreochromis niloticus in Lake Kariba, Zimbabwe, following escape from fish farms. In Stocking and Introduction of Fish, Cowx IG (ed). Fishing News Books: Oxford; 267- 273.

Colnar A, Landis W. 2007. Conceptual model development for invasive species and a regional assessment case study: the European Green Crab, Carcinus maenas, at Cherry Point, Washington, USA. Human and Ecological Risk Assessment 13: 120-155.

Copp GH, Garthwaite R, Gozlan RE. 2005. Risk identification and assessment of non-native freshwater fishes: concepts and perspectives on protocols for the UK. CEFAS, Sciences Series technical report no.129.

Costa-Pierce BA. 2003. Rapid evolution of an established feral population (Oreochromis spp.): the need to incorporate invasion science into regulatory structures. Biological Invasions 5: 71-84.

Cowx IG. 1999. An appraisal of stocking strategies in the light of developing country constraints. Fisheries Management and Ecology 6: 21-34.

D’Amato ME, Esterhuyse MM, van der waal BWC, Brink D, Volckaert AM. 2007. Hybridisation and phylogeography of the Mozambique tilapia Oreochromis mossambicus 
in southern Africa evidenced by mitochondrial and microsatellite DNA genotyping. Conservation Genetics 8: 475-488.

Daget J, Gosse JP, Teugels GG, Thys van den Audenaerde DFE. 1991. Check-list of the freshwater fishes of Africa (CLOFFA). ISNB, Brussels, MRAC, Tervuren and ORSTOM, Paris. Vol. 4.

Davies BR, O’Keeffe JH, Snaddon CD. 1995. River and stream ecosystems in Southern Africa: predictably unpredictable. In River and Stream Ecosystems: Ecosystems of the World, Cushing CE, Cummins KW, O’Keeffe JH (eds). Elsevier: Amsterdam; 537-599.

Davies BR, Thoms M, Meador M. 1992. An assessment of the ecological impacts of inter-basin water transfers, and their threats to river basin integrity and conservation. Aquatic Conservation: Marine and Freshwater Ecosystems 2: 325-349.

Davies BR, Wishart MJ. 2000. River conservation in the countries of the Southern African Development Community (SADC). In Global Perspectives on River Conservation: Science, Policy and Practice, Boon PJ, Davies BR, Petts GE (eds). John Wiley: Chichester; 179-204.

de Moor IJ, Bruton MN. 1988. Atlas of alien and translocated indigenous aquatic animals in southern Africa. Pretoria: South African National Scientifc Programmes Report no.144.

de Vos L, Snoeks J, Thys van den Audenaerde D. 1990. The effects of tilapia introductions in Lake Luhondo, Rwanda. Environmental Biology of Fishes 27: 303-308.

Elith J, Graham CH, Anderson RP, Dudík M, Ferrier S, Guisan A, Hijmans RJ, Huettmann F, Leathwick JR, Lehmann A, et al. 2006. Novel methods improve prediction of species' distributions from occurrence data. Ecography 29: 129-151. 
Elith J, Leathwick JR. 2009. Species distribution models: ecological explanation and prediction across space and time. Annual Review of Ecology, Evolution and Systematic 40: 677-97.

Figueredo CC, Giani A. 2005. Ecological interactions between Nile tilapia (Oreochromis niloticus, L.) and the phytoplanktonic community of the Furnas Reservoir (Brazil). Freshwater Biology 50: 1391-1403.

Fitzpatrick M, Hargrove W. 2009. The projection of species distribution models and the problem of non-analog climate. Biodiversity and Conservation 18: 2255-2261.

Fitzpatrick MC, Weltzin JF, Sanders NJ, Dunn RR. 2008. The biogeography of prediction error: why does the introduced range of the fire ant over-predict its native range? Global Ecology and Biogeography 16:24-33.

Getabu A. 1994. A comparative study on feeding habits of Oreochromis niloticus (Linnaeus) in Nyanza Gulf, Lake Victoria and sewage ponds. In Recent trends of research on Lake Victoria fisheries, Okemwa E, Wakwabi E, Getabu A (eds). ICIPE Science Press: Nairobi; 93-103.

Gophen M, Ochumba PBO, Pollinger U, Kaufman LS. 1993. Nile perch (Lates niloticus) invasion in Lake Victoria (East Africa). Verhandlungen der internationalen Vereinigung fur theoretische und angewandte Limnologie 25: 856-859.

Goudswaard PC, Witte F, Katunzi EFB. 2002. The tilapiine stock of Lake Victoria before and after the Nile Perch upsurge. Journal of Fish Biology 60: 838-856.

Gozlan RE, Britton JR, Cowx I, Copp GH. 2010. Current knowledge on non-native freshwater fish introductions. Journal of Fish Biology 76: 751-786.

Gozlan RE, St-Hilaire S, Feist SW, Martin P, Kent, ML. 2005. Biodiversity - disease threat to European fish. Nature 435:1046. 
Gratwicke B, Marshall BE. 2001. The relationship between the exotic predators Micropterus salmoides and Serranochromis robustus and native stream fishes in Zimbabwe. Journal of Fish Biology 58: 68-75.

Guisan A, Thuiller W. 2005. Predicting species distribution: offering more than simple habitat models. Ecology Letters 8: 993-1009.

Han M, Fukushima M, Kameyama S, Fukushima T, Matushita B. 2008. How do dams affect freshwater fish distributions in Japan? Statistical analysis of native and non-native species with various life histories. Ecological Research 23: 735-743.

Havel JE, Lee CE, Vander Zanden MJ. 2005. Do reservoirs facilitate invasion into landscapes? BioSciences 55: 518-525.

Igushi K, Matsuura K, McNyset KM, Peterson AT, Scachetti-Pereira R, Powers K, Vieglais D, Wiley EO, Yodo T. 2004. Predicting invasion of basses in Japan. Transactions of the American Fisheries Society 133: 845-854.

Jenness J, Dooley J, Aguilar-Manjarrez J, Riva C. 2007. African Water Resource Database. GIS-based tools for inland aquatic resource management. 2. Technical manual and workbook. CIFA Technical Paper. No. 33, Part 2. FAO, Rome.

Kapetsky JM. 1994. A strategic assessment of warm water fish farming potential in Africa. FAO, CIFA Technical Paper, No. 27.

Kleynhans CJ, Hoffman A. 1992. First record of Oreochromis macrochir (Boulenger, 1912) (Pisces: Cichlidae) from the Limpopo River in southern Africa. Southern African Journal of Aquatic Science 18: 104-106. 
Kleynhans CJ, Louw MD, Moolman J. 2007. Reference frequency of occurrence of fish species in South Africa. Report produced for the Department of Water Affairs and Forestry (Resource Quality Services) and the Water Research Commission.

Kolar C. 2004. Risk assessment and screening for potentially invasive fishes. New Zealand Journal of Marine and Freshwater Research 38: 391-397.

Kolar CS, Lodge DM. 2002. Ecological predictions and risk assessment for alien fishes in North America. Science 298: 1233-1236.

Landis WG. 2004. Ecological risk assessment conceptual model formulation for non-indigenous species. Risk Analyses 24: 847-858.

Lemarie G, Baroiller JF, Clota F, Lazard J, Dosdat A. 2004. A simple test to estimate the resistance of fish with specific application to $O$. niloticus and $S$. melanotheron. Aquaculture 240: 575-587.

Likongwe JS, Stecko TD, Stauffer JR, Carline RF. 1996. Combined effects of water temperature and salinity on growth and feed utilisation of Juvenile Nile Tilapia Oreochromis niloticus (Linneaus). Aquaculture 146: 37-46.

Linde AR, Izquierdo JI, Moreira JC, and Garcia-Vazquez E. 2008. Invasive tilapia juveniles are associated with degraded river habitats. Aquatic Conservation: Marine and Freshwater Ecosystems 18: 891-895.

Lockwood JL, Hoopes MF, Marchetti MP. 2007. Invasion Ecology. Blackwell Publishing: Oxford.

Lowe-McConnell RH. 2000. The role of tilapias in ecosystems. In Tilapias: Biology and Exploitation, Beveridge MCM, McAndrew BJ (eds). Kluwer: Dordrecht; 29-162. 
Marchetti MP, Light T, Moyle PB, Viers JH. 2004. Fish invasions in California watersheds:

testing hypotheses using landscape patterns. Ecological Applications 14: 1507-1525.

Marshall BE, Gratwicke B. 1999. The barred minnows (Teleostei: Cyprinidae) of Zimbabwe: is there cause for concern. Southern African journal of Aquatic Science 24:157-161.

Marshall BE. 2000. Freshwater fishes of the Zambezi basin. In: Timberlake J (ed) Biodiversity of the Zambezi Basin Wetlands. Occasional Publications in Biodiversity No 8. Biodiversity Foundation for Africa, Bulawayo/Zambezi Society: Harare; 393-459.

Marshall BE. 2006. A checklist of the fishes of Lake Kariba (Zimbabwe-Zambia). Arnoldia Zimbabwe 10: 257-274.

McCrary JK, Murphy BR, Stauffer JR, Hendrix SS. 2007. Tilapia (Teleostei: Cichlidae) status in Nicaraguan natural waters. Environmental Biology of Fishes 78: 107 - 114.

McNyset KM. 2005. Use of ecological niche modelling to predict distributions of freshwater fish species in Kansas. Ecology of Freshwater Fish 14: 243-255.

Minshull JL. 2008. Dry season fish survival in isolated pools and within sand-beds in the Mzingwane River, Zimbabwe. African Journal of Aquatic Science 33: 95-98.

Moralee RD, van der Bank FH, van der Waal BCW. 2000. Biochemical genetic markers to identify hybrids between the endemic Oreochromis mossambicus and the alien species, $O$. niloticus (Pisces: Cichlidae). Water SA 26: 263-268.

Moriarity CM, Moriarity DJM. 1973. The assimilation of carbon from phytoplankton by two herbivorous fishes: Tilapia nilotica and Haplochromis nigripinnis. Journal of Zoology, London 171: 41-56.

National Research Council. 2002. Predicting Invasions of Non-indigenous Plants and Plant Pest. National Academic Press, Washington DC. 
NEPAD. 2005. The NEPAD action plan for the development of African fisheries and aquaculture. The New Partnership for Africa's Development (NEPAD) - Fish for All Summit, Abuja Nigeria, 23 August 2005. Available from the Internet: URL http://www.fishforall.org/ffa-summit/English/NEPAD ActionPlan.pdf.

Njiru M, Okeyo-Owuor JB, Muchiri M, Cowx IG, van der Knaap M. 2007. Changes in population characteristics and diet of Nile tilapia Oreochromis niloticus (L.) from Nyanza Gulf of Lake Victoria, Kenya: what are the management options? Aquatic Ecosystem Health \& Management 10: 434-442.

Njiru M, Okeyo-Owuor JB, Muchiri M, Cowx IG. 2004. Shifts in the food of the Nile tilapia, Oreochromis niloticus (L.) in Lake Victoria, Kenya. African Journal of Ecology 42: 163170.

Njiru M, Waithaka E, Muchiri M, Van Knaap M, Cowx IG. 2005. Exotic introductions to the fishery of Lake Victoria: what are the management options? Lakes \& Reservoirs: Research and Management 10: 147-155.

Ogutu-Ohwayo R, Hecky RE. 1991. Fish introductions in Africa and some of their implications. Canadian Journal of Fisheries and Aquatic Science 48: 8-12.

Ojuok JE, Njiru M, Ntiba MJ, Mavuti KM. 2007. The effect of overfishing on the life-history strategies of Nile tilapia, Oreochromis niloticus (L.) in the Nyanza Gulf of Lake Victoria, Kenya. Aquatic Ecosystem Health \& Management 10: 443-448.

Payne AI, Collinson RI. 1983. A comparison of the biological characteristics of Sarotherodon niloticus (L.) with those of Surotherodon nureus (Steindachner) and other tilapia of the Delta and lower Nile. Aquaculture 30: 335-351. 
Peterson AT, Nakazawa Y. 2008. Environmental data sets in ecological niche modelling: an example of with Solenopsis invicta and Solenopsisrichteri. Global Ecology and Biogeography 17: 135-144.

Pheloung PC, Williams PA, Halloy SR. 1999. A weed risk assessment model for use as a biosecurity tool evaluating plant introductions. Journal of Environmental Management 57: 239-251.

Philippart JCL, Ruwet JCL. 1982. Ecology and Distribution of Tilapias. In The Biology and Culture of Tilapias, Pullin RSV, Lowe-McConnell RH (eds). International Centre for Living Aquatic Resources Management. (ICRAM) conference proceedings 7: 15-60.

Pimentel D, Zuniga R, Morrison D. 2005. Update on the environmental and economic costs associated with alien-invasive species in the United States. Ecological Economics 52: 273288.

Pringle CM, Freeman MC, Freeman BJ. 2000. Regional effects of hydrologic alterations on riverine macrobiota in the new world: tropical-temperate comparisons. BioScience 9: 807823.

Pullin RSV, Palomares M, Casal C, Dey M, Pauly D. 1997. Environmental impacts of Tilapia. In Tilapia Aquaculture: Proceedings of the Fourth International Symposium on Tilapia in Aquaculture, Fitzsimmons, K. (ed). Northeast Regional Aquacultural Engineering Services Publication No. NRAES- 106: New York; $554-570$.

Rödder D, Lötters S. 2009. Niche shift versus niche conservatism? Climatic characteristics of the native and invasive ranges of the Mediterranean house gecko (Hemidactylus turcicus). Global Ecology and Biogeography 18: 674-687. 
Rödder D, Lötters S. 2010. Explanative power of variables used in species distribution modeling: $\mathrm{n}$ issue of general model transferability or niche shift in the invasive green frog (Eleutherodactylus planirostris). Naturwissenschaften 97: 781-796.

Rödder D, Schmidtlein S, Veith M, Lötters S. 2009. Alien invasive slider turtle in unpredicted habitat: a matter of niche shift or of predictors studied? PloS One 4: e7843.

Ross LG. 2000. Environmental Physiology and Energetics. In Tilapias: Biology and Exploitation, Beveridge MCM, McAndrew (eds). Kluwer Academic Publishers: London; $89-128$.

Sala OE, Chapin FS, Armesto JJ, Berlow E, Bloomfield J, Dirzo R, Huber-Sanwald E, Huenneke LF, Jackson RB, Kinzig A, et al. 2000. Biodiversity - global biodiversity scenarios for the year 2100. Science 287: 1770-1774.

Schleier JJ, Sing SE, Peterson RKD. 2008. Regional ecological risk assessment for the introduction of Gambusia affinis (western mosquitofish) into Montana watersheds. Biological Invasions 10: 1277-1287.

Schwank EJ. 1995. The introduced Oreochromis niloticus is spreading on the Kafue floodplain, Zambia. Hydrobiologia 315: 143-147.

Seehausen O, van Alphen JJM, Witte F. 1997. Cichlid fish diversity threatened by eutrophication that curbs sexual selection. Science 277: 1808-1811.

Shipton T, Tweddle D, Watts M. 2008. Introduction of the tilapia (Oreochromis niloticus) into the Eastern Cape. Species risk assessment. The Eastern Cape Development Corporation, Risk assessment report 1- 29.

Shoemaker CA, Xu DH, Evans JJ, Klesius PH. 2006. Parasites and Diseases. In Tilapia: Biology, Culture and Nutrition, Lim CE, Webster CD (eds). Haworth Press: New York; 561- 577. 
Sifa L, Chenhong L, Dey M, Gagalac F, Dunham R. 2002. Cold tolerance of three strains of Nile Tilapia, Oreochromis niloticus, in China. Aquaculture 213: 123-129.

Simberloff D. 2003. How much information on population biology is needed to manage introduced species? Conservation Biology 17: 83-92.

Skelton PH. 1990. The conservation and status of threatened fishes in southern African. Journal of Fish Biology 37: 87-95.

Skelton PH. 2001. A Complete Guide to the Freshwater Fishes of Southern Africa. Struik Publishers: Cape Town.

Starling F, Lazzaro X, Cavalcanti C, Moreira R. 2002. Contribution of omnivorous tilapia to eutrophication of a shallow tropical reservoir: evidence from a fish kill. Freshwater Biology 47: 2443-2452.

Suresh V. 2003. Tilapias. In: Aquaculture: farming aquatic animals and plants, Lucas JS, Southgate PC (eds). Blackwell Publishing: Oxford; 321-345.

Trewavas E. 1983. Tilapiine fishes of the genera Sarotherodon, Oreochromis and Danakilia. British Natural History Museum: London.

Tweddle D, Bills R, Swartz E, Coetzer W, Da Costa L, Engelbrecht L, Cambray J, Marshall B, Impson D, Skelton PH, et al. 2009. The status and distribution of freshwater fishes. In The status and distribution of freshwater biodiversity in southern Africa, Darwall WRT, Smith KG, Tweddle D, Skelton P (eds). IUCN: Gland, Switzerland and SAIAB: Grahamstown, South Africa.

Tweddle D, Wise RM. 2007. Nile Tilapia. In The Economic Impact and Appropriate Management of Selected Invasive Alien Species on the African Continent, Wise RM, van 
Wilgen BW, Hill MP, Schulthess F, Tweddle D, Chabi-Olay A, Zimmermann HG (eds). Global Invasive Species Programme: CSIR/NRE/RBSD/ER/2007/0044/C; 43.

Twongo T. 1995. Impact of fish species introduction on the tilapias of lakes Victoria and Kyoga. In The impact of species changes in African lakes, Pitcher JH, Hart PJB (eds). Fish and Fisheries Series, Chapman and Hall: London; 45-57.

Uys MC, O’Keeffe JH. 1997. Simple Words and Fuzzy Zones: Early Directions for Temporary River Research in South Africa. Environmental Management 21: 517-531.

van der Mheen, H. 1997. Review of introduction and translocation of aquatic species in the Limpopo river system and regional co-operation for policy development. ALCOM Report No. 25 .

van der Waal BCW, Bills R. 1997. Oreochromis niloticus in the Limpopo System. Ichthos 52: 14-16.

van der Waal BCW, Bills R. 2000. Oreochromis niloticus (Teleostei: Cichlidae) now in the Limpopo River System. South African Journal of Science 96: 47-48.

van der Waal BCW. 1997. Some observations on the fish life in a seasonal sand river. Southern African Journal of Aquatic Science 23: 95-102.

van Schoor DJ. 1966. Studies on the culture and acclimation of Tilapia in the Western Cape Province. Department of Nature Conservation, Cape Provincial Administration. Investigation Report No. 7.

Vander Zanden MJ, Olden JD. 2008. A management framework for preventing the secondary spread of aquatic invasive species. Canadian Journal of Aquatic Science 65: 1512-1522. Villegas CT. 1990. Evaluation of the salinity tolerance of Oreochromis mossambicus, O. niloticus and their $\mathrm{F}_{1}$ hybrids. Aquaculture 85: 281-292. 
Watanabe WO, Kuo CM, Huang MC. 1985. Salinity resistance of Nile tilapia fry (Oreochromis niloticus), spawned and hatched at various salinities. Aquaculture 48: 159- 176.

Webb AC. 2006. Risk assessment screening for potentially invasive freshwater fishes within the wet tropics bioregion: a review of assessment approaches, identification of knowledge gaps and future recommendations. Draft report No. 06/26. Australian Centre for Tropical

Freshwater Research.

Welcomme RL. 1988. International introductions of inland aquatic species. FAO Fisheries Technical Paper: FAO, Rome.

Wetzel GW. 2001. Limnology. Lakes and river ecosystems. Academic Press. London.

Weyl OLF. 2008. Rapid invasion of a subtropical lake fishery in central Mozambique by Nile tilapia, Oreochromis niloticus (Pisces: Cichlidae). Aquatic Conservation: Marine and Freshwater Ecosystems 18: 839-851.

Wise RM, van Wilgen BW, Hill MP, Schulthess F, Tweddle D, Chabi-Olay A, Zimmermann HG. 2007. The economic impact and appropriate management of selected invasive alien species on the African continent. Global Invasive Species Programme: CSIR/NRE/RBSD/ER/2007/0044/C.

Witte F, Goldschmidt T, Wanink J, Oijen M, Goudswaard K, Witte-Maas E, Bouton N. 1992. The destruction of an endemic species flock: quantitative data on the decline of the haplochromine cichlids of Lake Victoria. Environmental Biology of Fishes 34: 1-28.

Woodford DJ, Impson ND. 2004. A preliminary assessment of the impact of alien rainbow trout (Oncorhynchus mykiss) on indigenous fishes of the upper Berg River, Western Cape Province, South Africa. African Journal of Aquatic Science 29: 107-111. 
Zambrano L, Martínez-Meyer E, Menezes N, Peterson TA. 2006. Invasive potential of common carp (Cyprinus carpio) and Nile tilapia (Oreochromis niloticus) in American freshwater systems. Canadian Journal Fisheries and Aquatic Sciences 63: 1903-1910.

Zengeya TA, Booth AJ, Bastos ADS, Chimimba CT. 2011. Trophic interrelationships between the exotic Nile tilapia, Oreochromis niloticus and indigenous tilapiine cichlids in a subtropical African river system (Limpopo River, South Africa). Environmental Biology of Fishes 92: 479-489.

Zengeya TA, Marshall BE. 2007. Trophic interrelationships amongst cichlid fishes in a tropical African reservoir (Lake Chivero, Zimbabwe). Hydrobiologia 592: 175-182. 
Figure captions

Fig. 1 The invasion vulnerability scores (IVS) for the establishment and spread of Nile tilapia (Oreochromis niloticus) across the river systems in the Limpopo River basin, northern South Africa. Potential distribution is indicated by shaded areas, with red and green indicating high and low invasion vulnerability scores (IVS), respectively. Circles $(\bullet)$ indicate the presence of dams.

Fig. 2 The invasion impact scores (IIS) for the establishment and spread of Nile tilapia (Oreochromis niloticus) across the river systems in the Limpopo River basin, northern South Africa. Potential ecological impact is indicated by shaded areas, with red and green indicating high and low invasion impact scores (IIS), respectively. Circles $(\bullet)$ indicate the presence of dams. 
Table 1 A list of species of concern (SOC) and introduced species (IS) in the Limpopo River basin, northern South Africa.

\begin{tabular}{lll}
\hline Common name & Scientific name & SOC or IS \\
\hline & & \\
Southern barred minnow & Opsaridium peringueyi & SOC \\
Mozambique tilapia & Oreochromis mossambicus & SOC \\
Mosquito fish & Gambusia affinis & IS \\
Rainbow trout & Oncorhynchus mykiss & IS \\
Largemouth bass & Micropterus salmoides & IS \\
Nile tilapia & Oreochromis niloticus & IS \\
\hline
\end{tabular}


Figures

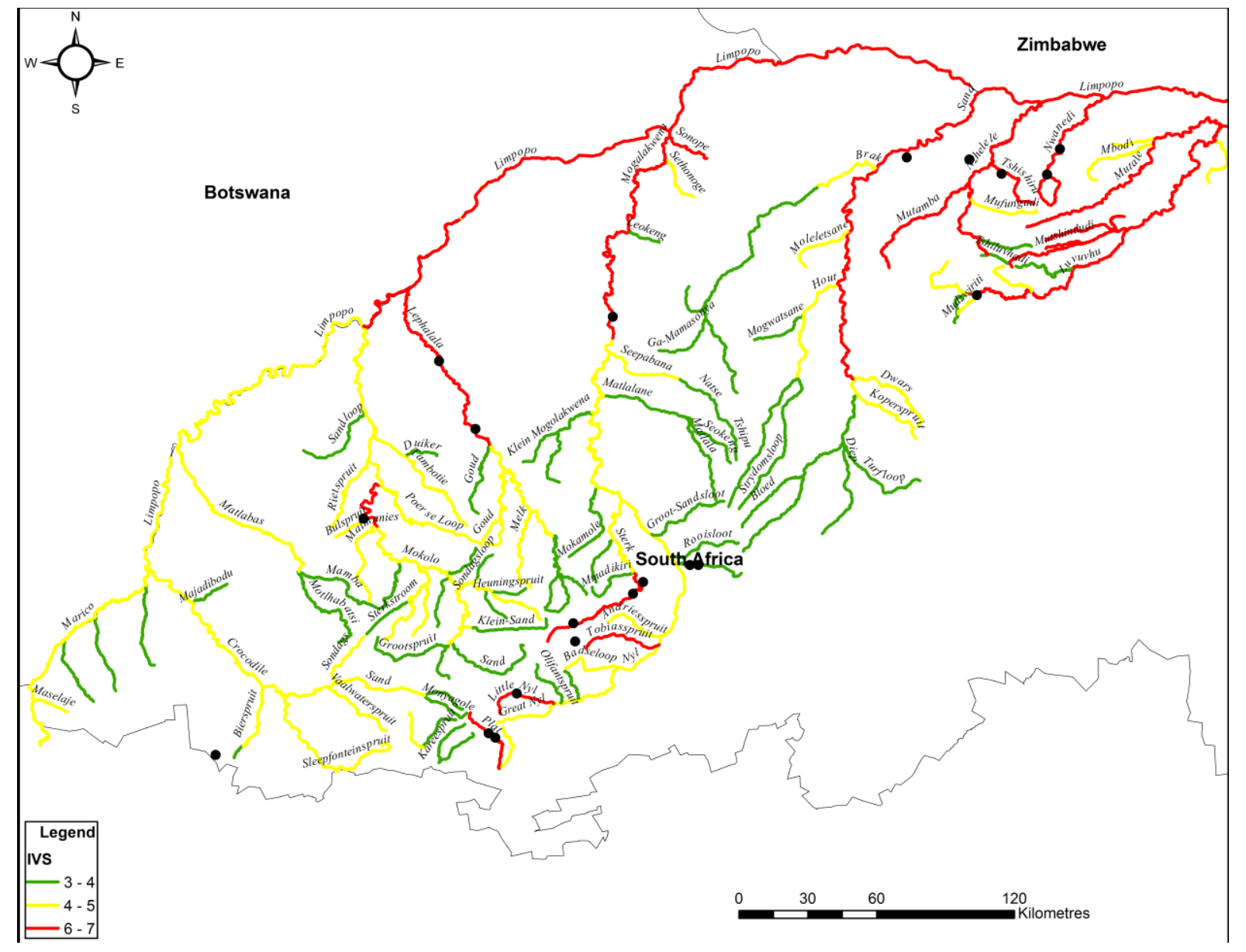

Figure 1. Zengeya et al. 


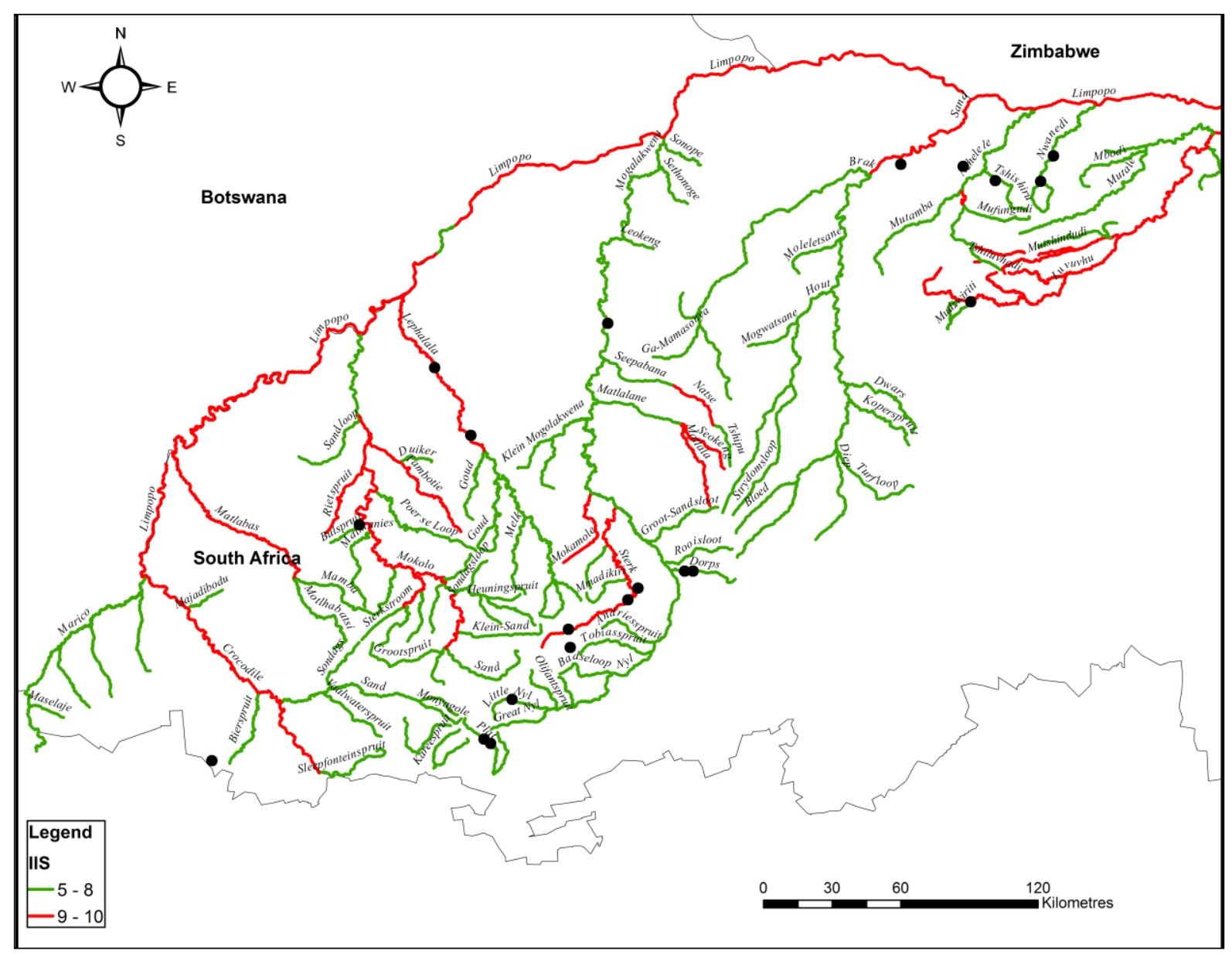

Figure 2. Zengeya et al. 